\title{
Prevalence of Campylobacter species in milk and milk products, their virulence gene profile and antibiogram
}

\author{
Shivani Modi, M. N. Brahmbhatt, Y. A. Chatur and J. B. Nayak \\ Department of Veterinary Public Health and Epidemiology, College of Veterinary Science \& Animal Husbandry, \\ Anand Agricultural University, Anand, Gujarat, India. \\ Corresponding author: Shivani Modi, e-mail: drshivani30@gmail.com, MNB: mnbrahmbhatt2003@yahoo.com, \\ YAC: dr.yogesh223@gmail.com, JBN: jbn anand@yahoo.com \\ Received: 05-08-2014, Revised: 22-11-2014, Accepted: 29-11-2014, Published: 02-01-2015
}

doi: 10.14202/vetworld.2015.1-8. How to cite this article: Modi S, Brahmbhatt MN, Chatur YA, Nayak JB(2015) Prevalence of Campylobacter species in milk and milk products, their virulence gene profile and antibiogram, Veterinary World 8(1): 1-8.

\begin{abstract}
Aim: During the last decades, number of food poisoning cases due to Campylobacter occurred, immensely. After poultry, raw milk acts as a second main source of Campylobacter. Therefore, the present study was undertaken to detect the prevalence of Campylobacters in milk and milk products and to know the antibiotic sensitivity and virulence gene profile of Campylobacter spp. in Anand city, Gujarat, India.
\end{abstract}

Material and Methods: A total of 240 samples ( 85 buffalo milk, 65 cow milk, 30 cheese, 30 ice-cream and 30 paneer) were collected from the different collection points in Anand city. The samples were processed by microbiological culture method, and presumptive isolates were further confirmed by genus and species-specific polymerase chain reaction using previously reported primer. The isolates were further subjected to antibiotic susceptibility assay and virulence gene detection.

Result: Campylobacter species were detected in $7(2.91 \%)$ raw milk samples whereas none of the milk product was positive. All the isolate identified were Campylobacter jejuni. Most of the isolates showed resistance against nalidixic acid, ciprofloxacin, and tetracyclin. All the isolates have three virulence genes $c a d \mathrm{~F}, \mathrm{c} d t \mathrm{~B}$ and $f l g \mathrm{R}$ whereas only one isolate was positive for iamA gene and 6 isolates were positive for fla gene.

Conclusion: The presence of Campylobacter in raw milk indicates that raw milk consumption is hazardous for human being and proper pasteurization of milk and adaptation of hygienic condition will be necessary to protect the consumer from this zoonotic pathogen.

Keywords: antibiotic susceptibility, Campylobacter jejuni, polymerase chain reaction, virulence gene

\section{Introduction}

An infection that occurs due to consumption of food of animal origin is an important public health problem in all over the world [1]. Animal products that are mainly used for human consumption are meat of different animal, milk and the products that are made from them. In all these, milk and milk products are mainly used as a dietary source by Indians [2]. Raw milk acts as the main source for various pathogens such as Escherichia coli, Mycobacterium bovis, Listeria monocytogenes, Campylobacter, Brucella and Salmonella [3]. In all these, Campylobacters the leading cause of zoonotic infections in many countries and the public health burden due to Campylobacteriosis is increasing day to day [4]. It is a gastrointestinal disorder that mainly affects infants, elderly people, patients with underlying disease and immunocompromised individuals. Campylobacteriosis is usually a self-limited disease, and antimicrobial therapy is not generally indicated $[5,6]$.

The family Campylobacteraceae consists of four genera, comprising Campylobacter, Arcobacter,

Copyright: The authors. This article is an open access article licensed under the terms of the Creative Commons Attributin License (http:// creative commons.org/licenses/by/2.0) which permits unrestricted use, distribution and reproduction in any medium, provided the work is properly cited.
Dehalospirilum, and Sulfurospirilum. Under this genus campylobacter consists of 32 species and 13 subspecies [7]. They are motile, curved S- or spiral shaped Gram-negative rods, 0.2-0.8 $\mu \mathrm{m}$ wide and 0.5-5 $\mu \mathrm{m}$ long [7]. In all the species, Campylobacter jejuni and Campylobacter coli are most important from food safety point of view and causes enteritis in domestic animal and human being $[4,6]$.

Campylobacters are inhabitants in the intestinal tract of a wide variety of wild and domestic animals, especially birds [8]. Inadequately cooked meat, particularly poultry, unpasteurized milk, contaminated drinking water, ready to eat food products, direct contact with animals, fecal runoff of domestic animals and birds contaminating surface water act as main source of organism [9-11]. Raw milk is primarily to be contaminated by bovine feces. However, direct contamination of milk as a consequence of mastitis also occurs [12].

It causes diarrhea and abortion in animals. In human being, the gastroenteritis due to Campylobacter ranges from mild to severe diarrheal disease. Instead of diarrhea (often bloody diarrhea), other symptoms are cramping, abdominal pain and fever within 2-5 days after exposure to the organism, with symptoms typically lasting 1 week [5]. Complications that occur due to Campylobacter are Guillain-Barre 
syndrome, reactive arthritis, hemolytic uraemic syndrome and meningitis, etc. [13]. Though infections due to $C$. jejuni are rare, and most patients do not need specific interventions. However, emergence of antimicrobial resistant Campylobacters had increased the chances of increased invasive illness [14]. The increased prevalence of this resistant campylobacter has been linked to the illegitimate use of antimicrobials in food animals, animal feeds and flock treatment of animals rather than the individual approach [15].

Despite the increased recovery of Campylobacters as a food borne pathogen, the specific virulence and pathogenic mechanisms by which microaerophilic Campylobacter species causes infection are still poorly understood [16]. The putative virulence factor for adhesion and invasion of epithelial cells, toxin production, and flagellar motility are thought to be important virulence mechanisms[17]. But, different studies have indicated that different virulence marker could play a role of colonization, adherence, and invasion of Campylobacter spp. in the animal and human being.

Campylobacter infection are sporadic in nature and have worldwide occurrence [18-23]. In UK, it is the principal cause of gastroenteritis while in United States; it is fifth domestically acquired foodborne infection [24]. It is the most common notifiable foodborne disease in Austria, Denmark, Finland, Germany, Italy, Sweden, and Norway $[25,26]$. Due to less information about Campylobacter in milk and milk products in India, this study was projected to characterize the Campylobacter isolates from milk and milk products to know the prevalence and antibiotic resistance pattern of Campylobacter spp. in Anand city, Gujarat, India.

\section{Material and Methods}

\section{Ethical approval}

The study entailed the collection of milk samples from farmer's cattle milk from collection points, retail shop and vendor. Ethical approval was obtained Ethical Review Committee, Veterinary Science College, AAU, Anand, Gujarat. Farmers, person in charge of units and shops were informed about study and verbal consent was taken before collection of samples.

\section{Source of experimental samples}

A total of 240 samples comprising raw milk ( 85 buffalo and 75 cow milk), cheese (30), ice-cream (30) and paneer (30) were collected from different collection points, retail shops and vendors in and around the Anand city in sterilized container in ice pack and processed within $2 \mathrm{~h}$.

\section{Enrichment and plating of milk and milk product samples}

Samples were processed to isolate the Campylobacter spp. as per the method described by Salihu et al. [27]. In brief, $\mathrm{pH}$ of milk samples was adjusted at 7.5 and $20 \mathrm{ml}$ of milk was centrifuged at $14,000 \mathrm{rpm}$ for $20 \mathrm{~min}$. at $4^{\circ} \mathrm{C}$. The pellet was suspended in $45 \mathrm{ml}$ of Preston enrichment broth base containing Preston enrichment supplement, Campylobacter growth supplement (HiMedia Laboratories, Mumbai, India) and 5\% (v/v) defibrinated sheep blood in $100 \mathrm{ml}$ sterile screw cap flask. For dairy product samples, $25 \mathrm{~g}$ of samples were homogenized in normal saline and transferred to $225 \mathrm{ml}$ of Preston enrichment broth base containing Campylobacter selective supplement IV (HiMedia Laboratories, Mumbai, India) and 5\% (v/v) defibrinated sheep blood, mixed properly and incubated at microaerophilic environment $\left(85 \% \mathrm{~N}_{2}, 5 \% \mathrm{O}_{2}\right.$ and $10 \% \mathrm{CO}_{2}$ ) in water jacketed $\mathrm{CO}_{2}$ incubator (NUÂRE, Polymouth, MN, USA) at $42^{\circ} \mathrm{C}$ for $42 \mathrm{~h}$. After enrichment culture, a loopful of enriched culture was streaked on blood free charcoal cefoperazone deoxycholate agar medium plates [27]. For selective isolation typical due drop like colonies were isolated on blood agar with 5\% defibrinated sheep blood to obtain pure cultures. The inoculated plates were incubated at microaerophilic environment $\left(85 \% \mathrm{~N}_{2}, 5 \% \mathrm{O}_{2}\right.$ and $10 \% \mathrm{CO}_{2}$ ) at $42^{\circ} \mathrm{C}$ for $48 \mathrm{~h}$.

\section{Presumptive identification of isolates}

Three or four Campylobacter-like colonies were picked from each plate and subjected to gram staining and oxidase, catalase, indoxyl acetate, hippurate hydrolysis test, $\mathrm{H}_{2} \mathrm{~S}$ production and nitrate reduction test $[21,28]$.

\section{DNA extraction}

The DNA was extracted by heat and snap chilling method. The two to three colonies of fresh bacterial growth on culture medium was collected, suspended in nuclease-free demonized water and heated at $95^{\circ} \mathrm{C}$ for $10 \mathrm{~min}$. The samples were cooled immediately and centrifuge for $5 \mathrm{~min}$ at room temperature. The supernatant was separated, and $3 \mu 1$ was used as DNA template.

\section{Confirmation and species identification of isolates using polymerase chain reaction (PCR)}

The biochemically identified isolates were further employed for confirmation as genus Campylobacter and species $C$. jejuni and C. coli, by polymerase chain reaction amplifying specific target gene using genus and species-specific oligonucleotide primers. The primer sequence and size of target PCR product is shown in Table-1. The DNA amplification for each primer pair was carried out in a Applied Biosystems 2720 Thermal Cycler in $25 \mu 1$ reaction containing $3 \mu 1$ of DNA template, $12.5 \mu 1$ mastermix (Thermo Scientific, USA) (containing 0.05 unit/ $\mu 1$ Taq DNA Polymerase, reaction buffer, $4 \mathrm{mM} \mathrm{MgCl}, 0.4 \mathrm{mM}$ of each dNTP), 10 pmole of each forward and reverse primer $(10 \mathrm{pmole} / \mu \mathrm{l})$, and $7.5 \mathrm{ml}$ nuclease free water with positive and negative control. The control strains of C. jejuni and C. coli isolates in our department were used for positive control whereas DNase free distilled water was used for negative control. The cycling protocol for the genus confirmation was standardized to 
Table 1: List of the genus and species specific primers.

\begin{tabular}{|c|c|c|c|c|}
\hline Gene name & Primer Sequence & Target gene & Amplicon size (bp) & Reference \\
\hline $\mathrm{C} 412 \mathrm{~F}$ & GGATGACACTITTCGGAGC & $\begin{array}{l}\text { Campylobacter genus } \\
\text { 16S rRNA }\end{array}$ & 816 & 78 \\
\hline C1228R & CATTGTAGCACGTGTGTC & & & \\
\hline Hip O1 & AGCTAGCTTCGCATAATAACTTG & $\begin{array}{l}\text { C. jejuni } \\
\text { Hippurase } \\
\text { Gene }\end{array}$ & 735 & 79 \\
\hline Hip $\mathrm{O} 2$ & GAAGAGGGTTTGGGTGGT & & & \\
\hline $\mathrm{CC} 1$ & GGTATGATTTCTACAAAGCGAG & $\begin{array}{l}\text { C. coli } \\
\text { Asperkinase gene }\end{array}$ & 500 & 79 \\
\hline $\mathrm{CC} 2$ & ATAAAAAGACTATCGTCGCGT & & & \\
\hline
\end{tabular}

C. coli=Campylobacter coli, C. jejuni=Campylobacter jejuni

set the PCR assay as initial denaturation at $95^{\circ} \mathrm{C}$ for 5 min followed by 35 cycles with denaturation at $95^{\circ} \mathrm{C}$ for $30 \mathrm{~s}$, annealing at $53^{\circ} \mathrm{C}$ for $30 \mathrm{~s}$ and extension at $72^{\circ} \mathrm{C}$ for $30 \mathrm{~s}$ and final extension at $72^{\circ} \mathrm{C}$ for $10 \mathrm{~min}$. For hippuricase (hipO) gene of Campylobacter jejuni, cycling condition was optimized to initial denaturation at $95^{\circ} \mathrm{C}$ for $5 \mathrm{~min}$, followed by 35 cycles with denaturation at $95^{\circ} \mathrm{C}$ for $45 \mathrm{~s}$, annealing at $51^{\circ} \mathrm{C}$ for $45 \mathrm{~s}$ and extension at $72^{\circ} \mathrm{C}$ for $45 \mathrm{~s}$ and final extension at $72^{\circ} \mathrm{C}$ for $7 \mathrm{~min}$ and for asperkinase $\mathrm{A}(\operatorname{ask} \mathrm{A})$ gene of $C$. coli cycling condition was optimized to initial denaturation at $95^{\circ} \mathrm{C}$ for $5 \mathrm{~min}$ followed by 35 cycles with denaturation at $95^{\circ} \mathrm{C}$ for $30 \mathrm{~s}$, annealing at $53^{\circ} \mathrm{C}$ for $30 \mathrm{~s}$ and extension at $72^{\circ} \mathrm{C}$ for $30 \mathrm{~s}$ and final extension at $72^{\circ} \mathrm{C}$ for $7 \mathrm{~min}$. On completion of the reaction, the amplified products were held briefly at $4^{\circ} \mathrm{C}$. Amplification of the PCR products were detected by electrophoresis in $1.5 \%$ agarose gel with ethidium bromide $(10 \mu \mathrm{g} / \mathrm{ml})$ in $0.5 \mathrm{X}$ TBE buffer (Sigma, USA) at $100 \mathrm{~V}$ for $40 \mathrm{~min}$ and documented in G: BOXF3 (SynGene, USA).

\section{In vitro antimicrobial drug resistance pattern}

All the Campylobacter isolates were subjected for antibiotic susceptibility test by Kirby-Bauer disc diffusion method according to the Clinical Laboratory Standards Institute (CLSI) [29] for seven antibiotics as ciprofloxacin $(5 \mathrm{mcg})$, chloramphenicol $(30 \mathrm{mcg})$, nalidixic acid $(30 \mathrm{mcg})$, erythromycin $(15 \mathrm{mcg})$, gentamicin (10 mcg), Streptomycin sulphate $(30 \mathrm{mcg})$ and Tetracycline $(30 \mathrm{mcg})$ as suggested by External Quality Assurance System [30]. Isolates were grown on nutrient broth No. 2 at $37^{\circ} \mathrm{C}$ for $24 \mathrm{~h}$. The individual broth culture was then smeared on the surface of Mueller-Hinton agar (Hi Media) supplemented with $5 \%$ defibrinated sheep blood with the help of sterile cotton swab. The plates were allowed to dry for few minutes. Antibiotic disc was placed on the agar surface within $15 \mathrm{~min}$ of inoculation of the plates. The plates were incubated overnight at $37^{\circ} \mathrm{C}$. Sensitivity or resistance of an isolate for a particular antibiotic was determined by measuring the diameter of the zone of growth inhibition. The result was interpreted as sensitive, intermediate or resistant by comparing with manufacturer's instructions. Culture of ATCC 33560 was used to check the quality for antibiotic sensitivity test.

\section{Virulence gene characterization of Campylobacter isolates}

The confirmed isolates of Campylobacter species were characterized for in vitro detection of virulence genes by PCR for five well-known virulence gene encoding flagellin gene (flaA) [31], campylobacter adherence gene $(c a d F)[32,33]$, invasion associated marker, iamA [34], flagellar synthesis and modification, flgR [16] and cytolethal distending toxin subunit $\mathrm{B}$ gene $(c d t \mathrm{~B})$ [35]. The details of primers for target virulence genes and PCR conditions are described in Table-2 and 3, respectively. The DNA of virulence gene positive control strains available in our department was used in PCR for detection of virulence genes while for negative control DNA template was replaced with nuclease-free distilled water. The positive control PCR revealed PCR product of appropriate size and in a negative control, no product was amplified.

\section{Results and Discussion}

Cultural plates that show typical dew drop like colonies were identified as Campylobacter. All the isolates were Gram-negative, spiral, curved or S-shaped rods, motile with characteristic darting screw type motility and showed oxidase and catalase positive reactions. All the isolates were positive for hippurate hydrolysis, indoxyl acetate, $\mathrm{H}_{2} \mathrm{~S}$ production, nitrate reduction and growth were further confirmed by genus-specific PCR by generating 816 bp of amplicon 16S rRNA sequence and species specific PCR by targeting $735 \mathrm{bp}$ and $500 \mathrm{bp}$ amplicon of hippurase (hip $\mathrm{O})$ and asperkinase (ask $\mathrm{A})$ gene for C. jejuni and C. coli, respectively.

The overall 2.91\% prevalence of Campylobacter was observed in total of 240 samples processed comprising 150 raw milk, 30 cheese, 30 paneer and 30 ice-cream. All the positive samples were obtained from raw milk (4.66\%), none of the milk product sample was found positive for Campylobacter. All the seven Campylobacter isolates were identified as C. jejuni $(100 \%)$ by species-specific PCR indicating that this species is distributed widely in the study area. The findings of the present study is concurrent with reports of Kazemeini et al. [36], Wysok et al. [37] and Rahimi et al.[38] where they observed almost similar 
Table 2: Oligonucleotide sequence of virulence genes.

\begin{tabular}{|c|c|c|c|c|}
\hline Target gene & Primer & Primer Sequence $\left(5^{\prime} \rightarrow 3^{\prime}\right)$ & Amplicon size (bp) & Reference \\
\hline Flagellin gene & $\begin{array}{l}\text { fla } 1 \\
\text { fla } 2\end{array}$ & $\begin{array}{l}\text { GGATTTCGTATTAACACAAATGGTGC } \\
\text { CTGTAGTAATCTTAAAACATITIG }\end{array}$ & 1725 & 80 \\
\hline Campylobacter adherence gene & $\begin{array}{l}\text { cad } F \\
\text { cad R }\end{array}$ & $\begin{array}{l}\text { TTGAAGGTAATTTAGATATG } \\
\text { CTAATACCTAAAGTTGAAAC }\end{array}$ & 400 & 66 \\
\hline Invasion associated marker & $\begin{array}{l}\operatorname{iam} F \\
\operatorname{iam} R\end{array}$ & $\begin{array}{l}\text { GCGCAAAATATTATCACCC } \\
\text { TTCACGACTACTATGCGG }\end{array}$ & 518 & 34 \\
\hline Flagellar synthesis and modification, flgR & $\begin{array}{l}\text { JL } 1225 \\
\text { JL } 1226\end{array}$ & $\begin{array}{l}\text { GAGCGTTTAGAATGGGTGTG } \\
\text { GCCAGGAATTGATGGCATAG }\end{array}$ & 390 & 16 \\
\hline Cytolethal distending toxin SubunitB gene & $\begin{array}{l}\text { CdtB-F } \\
\text { CdtB-R }\end{array}$ & $\begin{array}{l}\text { GTTGGCACTTGGAATTGGCAAGGC } \\
\text { GTTAAAATCCCCTGCTATCAACCA }\end{array}$ & 495 & 74 \\
\hline
\end{tabular}

Table 3: PCR cyclic condition of virulence genes.

\begin{tabular}{|c|c|c|c|c|c|}
\hline \multirow[t]{2}{*}{ Gene } & \multirow{2}{*}{$\begin{array}{c}\text { Initial } \\
\text { denaturation }\end{array}$} & \multicolumn{3}{|c|}{35 cycles } & \multirow{2}{*}{$\begin{array}{c}\text { Final } \\
\text { extension }\end{array}$} \\
\hline & & Denaturation & Annealing & Extension & \\
\hline \multirow[t]{2}{*}{ Flagellin gene } & $94^{\circ} \mathrm{C}$ & $94^{\circ} \mathrm{C}$ & $52^{\circ} \mathrm{C}$ & $72^{\circ} \mathrm{C}$ & $72^{\circ} \mathrm{C}$ \\
\hline & $5 \mathrm{~min}$ & $45 \mathrm{~s}$ & $45 \mathrm{~s}$ & $1 \mathrm{~min}$ & $10 \mathrm{~min}$ \\
\hline \multirow[t]{2}{*}{ Campylobacter adherence gene } & $94^{\circ} \mathrm{C}$ & $94^{\circ} \mathrm{C}$ & $45^{\circ} \mathrm{C}$ & $72^{\circ} \mathrm{C}$ & $72^{\circ} \mathrm{C}$ \\
\hline & $5 \mathrm{~min}$ & $1 \mathrm{~min}$ & $45 \mathrm{~s}$ & $1 \mathrm{~min}$ & $8 \mathrm{~min}$ \\
\hline \multirow{2}{*}{ Invasion associated marker } & $94^{\circ} \mathrm{C}$ & $94^{\circ} \mathrm{C}$ & $52^{\circ} \mathrm{C}$ & $72^{\circ} \mathrm{C}$ & $72^{\circ} \mathrm{C}$ \\
\hline & $5 \mathrm{~min}$ & $1 \mathrm{~min}$ & $1 \mathrm{~min}$ & $1 \mathrm{~min}$ & $5 \mathrm{~min}$ \\
\hline \multirow[t]{2}{*}{ Flagellar synthesis and modification, flgR } & $95^{\circ} \mathrm{C}$ & $95^{\circ} \mathrm{C}$ & $54^{\circ} \mathrm{C}$ & $72^{\circ} \mathrm{C}$ & $72^{\circ} \mathrm{C}$ \\
\hline & $5 \mathrm{~min}$ & $1 \mathrm{~min}$ & $1 \mathrm{~min}$ & $1 \mathrm{~min}$ & $5 \mathrm{~min}$ \\
\hline \multirow[t]{2}{*}{ Cytolethal distending toxin subunit B gene } & $95^{\circ} \mathrm{C}$ & $95^{\circ} \mathrm{C}$ & $57^{\circ} \mathrm{C}$ & $72^{\circ} \mathrm{C}$ & $72^{\circ} \mathrm{C}$ \\
\hline & $5 \mathrm{~min}$ & $30 \mathrm{~s}$ & $30 \mathrm{~s}$ & $30 \mathrm{~s}$ & $10 \mathrm{~min}$ \\
\hline
\end{tabular}

$\mathrm{PCR}=$ Polymerase chain reaction

prevalence rate i.e. $2.5 \%, 4.6 \%$ and $2.32 \%$, respectively. A lower prevalence rate of $1.5 \%$ and $1.41 \%$ was observed by Lovett et al. [39] in Cincinnati, Ohio, Canada and Elango et al. [40] in Chennai, India whereas some authors have not detected campylobacters in milk samples $[41,42]$. On the other hand, higher prevalence rate of $34 \%, 12.3 \%, 10.2 \%, 61 \%, 12.5 \%$, $12.5 \%, 66.8 \%, 3.06 \%$ and $8.07 \%$ was observed by Wicker et al. [43], Jayarao et al. [44], Hussain et al. [10], Martin et al. [45], Khanzadi et al. [46], Giacometti et al. [47], Mabotel et al. [48], Serraino et al. [49] and Giacometti et al. [50], respectively.

In the case of milk products, we did not found any positive sample which was concurrent with the study of Singh et al. [42] who could not detect campylobacters in cheese. In contrast to this Giacometti et al. [50] and Jain and Shrivastava [51] found the prevalence rate of $5.0 \%$ and $18.33 \%$ from traditional cheese while Vaishnavi et al. [52] identified the prevalence of $17.2 \%$ from paneer.

Although there is significant variation of the presence of Campylobacter in different food products as reported by different workers, milk act as a second main source of Campylobacter. The present study revealed that Campylobacter could be mainly transmitted through milk in comparison to milk products. The possible reason behind this may be destruction of an organism during the processing of milk products. It is mainly destroyed during the boiling of milk, so there are less chances of contamination of this pathogen in milk products. Contamination of milk products is only possible because of unhygienic conditions during the preparation of milk products.

In the present study, all the Campylobacter isolates were resistant to Nalidixic acid $(100 \%)$, whereas $6(85.71 \%)$ and $1(14.29 \%)$ isolates were resistant to ciprofloxacin and tetracyclin, respectively. One isolate was intermediate while $5(71.42 \%)$ isolates were sensitive to Tetracycline. All the isolates were sensitive for chloramphenicol, gentamicin, streptomycin sulfate and erythromycin. Only one isolates was sensitive for ciprofloxacin. The result is also in collaboration with Chatur et al. [53] who observed extremely high resistance of $C$. jejuni isolates to nalidixic acid and ciprofloxacin in study area. The presence of quinolone resistant campylobacter strains in the study area indicates the mutation in the gyrase subunit A gene that could be caused due to the treatment of animal with quinolones or their use in animal feed. As environment and water could act as the main source of contamination of milk due to unhygienic conditions, the presence of Campylobacter spp. from other animal species cannot be overruled. Looking into the increasing importance of Campylobacter sporadic outbreaks, this study suggests regular surveillance program for the detection and understanding the behavior of campylobacters. In Poland, Wysok et al. [37] and in Iran, Rahimi et al. [38] also obtained the same resistance pattern in their study while Murphy et al. [54] and Bopp et al. [55] found higher resistance against tetracycline.

In vitro detection of virulence genes revealed presence of $C a d, C d t \mathrm{~B}$ and $f l g \mathrm{R}$ genes in all the 


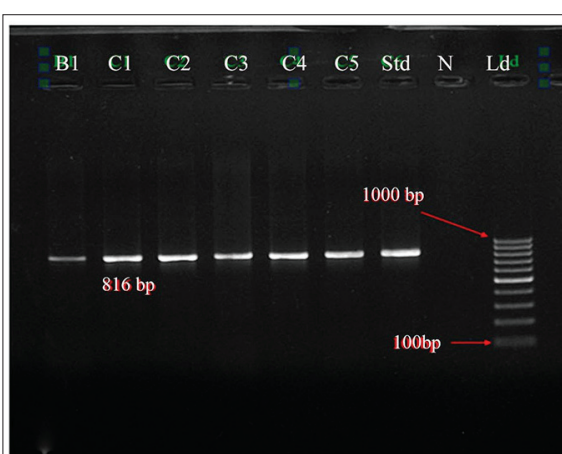

Genus specific gene (16S rRNA), $\sim 816 \mathrm{bp}$.

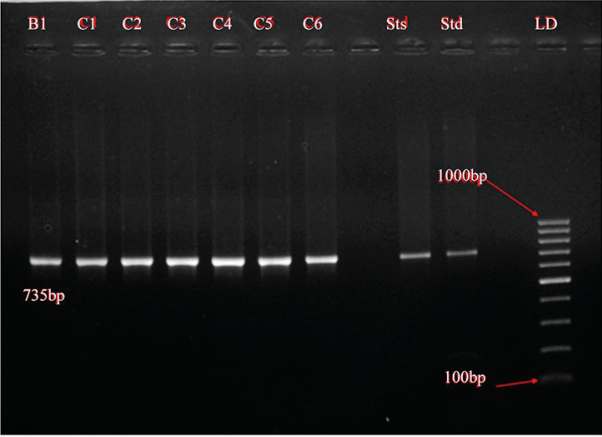

Species specific gene for $C$. jejuni (hipO), $\sim 750 \mathrm{bp}$

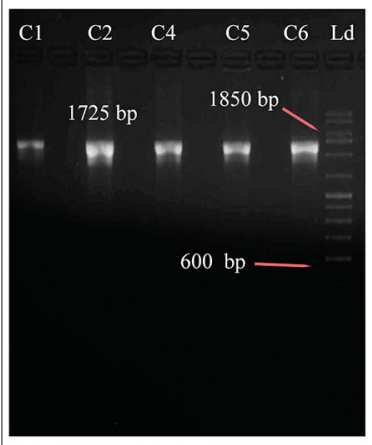

Flagellar gene (flaA), $\sim 1725 \mathrm{bp}$

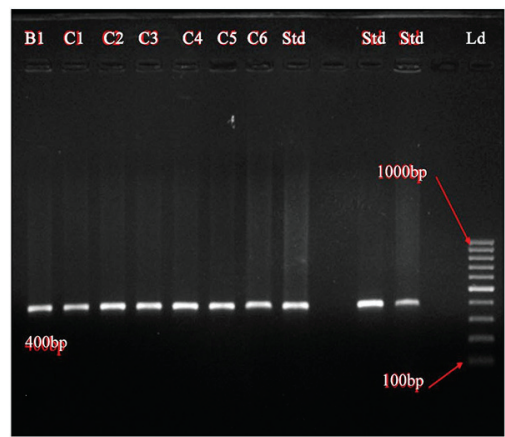

Campylobacter adherence factor ( $\mathrm{cadF}$ ) gene, $\sim 400 \mathrm{bp}$

Amplification of PCR products for the detection of Campylobacter spp.(A and $B$ ) and virulence genes (C, D, E, F and G).

Std- Positive control N- Negative control Ld- Marker

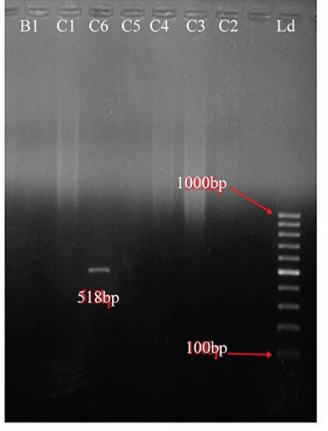

Invasion associated marker (iam A) gene, $\sim 518$ bp.

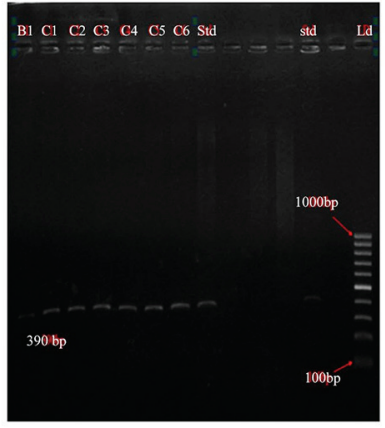

Flagellar synthesis and modification (flgR) gene, $\sim 390 \mathrm{bp}$.

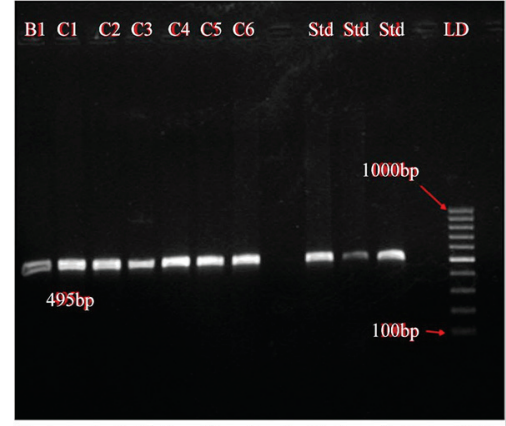

Cytolethal distending toxin Subunit B ( $c d t \mathrm{~B})$ gene, $\sim 495$ bp.

Figure-1: Amplification of PCR products for the detection of Campylobacter spp. and virulence genes

isolates while only one isolate was positive for iam $\mathrm{A}$ gene and 6 isolates were positive for flaA gene (Figure-1). The Flagellin gene encodes for a flagella protein that is responsible for motility, colonization of gastrointestinal tract and invasion of host cells [31]. Wegmuller et al. [56] detected only $6(6.5 \%)$ positive samples out of 93 samples in their study which was much lower in comparison to present study. This could be because of different primers used in this and present study. Campylobacter species are motile by means of a single polar, unsheathed flagellum at one or both ends of the organism. Two genes, fla $\mathrm{A}$ and $f l a \mathrm{~B}$, that are involved in the expression of the flagellar filament have been identified in C. jejuni $[57,58]$ and C. coli [59]. In both species, the two genes are arranged head-to-tail in the same direction, separated by $174 \mathrm{bp}$ having separate promoter region. In strains like C. jejuni, 81116, only flaA is expressed [58], whereas in C. coli VC167, some fla B is also expressed [59]. The fla A mutant strains of
C. jejuni has shown reduced motility and colonization $[60,61]$. The PCR can detect either one fla gene or two, depending on which primers are used. The primers are designed to bind strongly to conserved sequences, but the sequence in between the primers is highly variable and the primers were found to work for C. coli and C. upsaliensis as well [62]. Though, primer strongly binds in conserved sequences, we could not amplify the approximate $1725 \mathrm{bp}$ PCR product of flaA gene using the cited primers in one isolate (C3) obtained from cow raw milk. The mutation could have occurred in primer binding site on flaA gene may be due to sub culturing, or already mutant $C$. jejuni isolate in milk sample.

Presence of campylobacter adherence factor in all the isolates was in conformity with the report of Elango et al. [40] while it was higher as compared to the finding of Khanzadi et al. [46]. They observed the $15.5 \%$ occurrence of $c a d \mathrm{~F}$ gene among all Campylobacter isolates and only $8 \%$ in C. jejuni isolates. The results 
of present study agree with the data obtained by other authors, who examined and found $100 \%$ prevalence of $\mathrm{Cad}$ gene in Campylobacter isolates derived from different sources [63-66].

Among 7 isolates studied only one (14.28\%) isolates were positive for the presence of iam $\mathrm{A}$ gene and yielded the DNA fragment of 518bp. There was no any previous study for the presence of iamA gene in Campylobacter isolates that were isolated from milk but this gene was reported by different authors in those Campylobacter isolates that were obtained from meat or other sources [67-70].

All the seven isolates were positive for the presence of $f l g \mathrm{R}$ gene and yielded the DNA fragment of $390 \mathrm{bp}$. No any study was conducted previously for the presence of flgR gene in Campylobacter isolates isolated from milk. This gene encodes the signal-transduction regulatory protein responsible for flagellar synthesis and modification as a gene in response regulator of a two component system $(F \lg \mathrm{R} / \mathrm{S})$ and described by different authors responsible for phase variation is a mechanism whereby the bacteria can modify the antigenic make-up of its surface to evade the host immune system or adapt to new hosts or environments [71-73].

All the seven isolates were positive for the presence of $c d t \mathrm{~B}$ gene and yielded the DNA fragment of $495 \mathrm{bp}$. The absence of reports of screening of the Campylobacter isolates isolated from milk and milk products for the presence of $c d t \mathrm{~B}$ gene was the limitation for us to compare the result of the occurrence of $c d t \mathrm{~B}$ gene in this study. On the contrary, most of authors have detected this gene in Campylobacter isolates isolated from other food and clinical samples $[74,75]$ whereas it has also been detected in cattle beef and fecal samples [74,76,77].

\section{Conclusions}

Considering the zoonotic potential of this organism, in this study, we conclude that the raw milk and milk products act as the main source of Campylobacter, which is the leading cause of gastroenteritis worldwide. Due to its thermophilic nature, potential pathogenic character and the capability to grow in milk, monitoring and surveillance of this pathogen in raw milk and milk product should be necessary. It has been necessary to increase the activities for development of the concept for production of safe milk; maintain the hygienic condition at farm and processing unit and pasteurization of milk to protect the consumer.

\section{Author's Contributions}

SM supervised the overall research work. YAC and SM participated in sampling, analysis of samples and made available relevant literatures. MNB and JBN participated in draft and revision of the manuscript. All authors read and approved the final manuscript.

\section{Acknowledgments}

We express sincere thanks to College of Veterinary Science and A. H., Anand Agricultural University for providing infrastructure and Government of Gujarat state for providing fund for the project.

\section{Competing Interests}

Authors declares that they don't have any competing interests.

\section{References}

1. Venter, T. van de (2000) Emerging food-borne diseases: A global responsibility. Food Nutr. Agric., 26: 4-13.

2. Kishor, S. B. and Gabhane, D. (2012) Study of Impact of food inflation on middle class consumer's household consumption of milk with reference to Thane city. Abhinav Natl. Mon. Refereed J. Res. Commer. Manag., 1(4): 54-61.

3. Leedom, J. M., (2006) Milk of non human origin and infectious diseases in humans. Clin. Infect. Dis., 43(5): 610-615.

4. Center for Diseases Control and Prevention. (2007) Preliminary foodnet data on the incidence of infection with pathogen transmitted commonly through food- 10 states, United State, 2007. MMWR Morb. Mortal Wkly. Rep., 57: 57-70.

5. Murray, P. R., Baron, E. J., Jorgensen, J. H., Landry, M. L. and Pfaller, M.A., editors. (2007) Manual of Clinical Microbiology. $9^{\text {th }}$ ed. ASM Press, American Society of Microbiology, Washington, DC.

6. Nachamkin, I., Szymanski, C.M. and Blaser, M.J. (2008) Campylobacter. $3^{\text {rd }}$ ed. ASM Press, American Society for Microbiology, Washington, DC.

7. Vandamme, P., Debruyne, L., De Brandt, E. and Falsen, E. (2010) Reclassification of Bacteroidesureolyticus as Campylobacter ureolyticus comb. nov., and emended description of the genus Campylobacter. Int. J. Syst. Evol. Microbiol., 60: 2016-2022.

8. Altekruse, S. and Perez-Perez, G.I. (2006) Campylobacter jejuni and related organisms. In: Riemann, H.P. and Cliver, D.O., editors. Foodborne Infections and Intoxications. $3^{\text {rd }}$ ed. Academic Press, London. p259-287.

9. Humphrey, T.J. and Hart, R.J.C. (1988) Campylobacter and Salmonella contamination of unpasteurised cow's milk on sale to the public. J. Appl. Bacteriol., 65: 463-467.

10. Hussain, I., Mahmood, M.S., Akhtar, M. and Khan A. (2007) Prevalence of Campylobacter species in meat, milk and other food commodities in Pakistan. Food Microbiol, 24: $219-222$.

11. Whyte, P., McGill, K., Cowley, D., Madden, R. H., Moran, L., Scates, P., Carroll, C., O'Leary, A., Fanning, S., Collins, J. D., McNamara, E., Moore J. E. and Cormican, M. (2004) Occurrence of Campylobacter in retail foods in Ireland. Int. J. Food Microbiol., 95: 111-118.

12. Hudson, P.J., Vogt, R.L., Brondum, T. and Patton, C.M. (1984) Isolation of Campylobacter jejuni from milk during an outbreak of Campylobacteriosis. J. Infect. Dis., 150: 789-797.

13. Kopyta, I. and Wardak, S. (2008) Campylobacter jejuni infection in patient with Guillain Barre syndrome- Clinical case report. Med. Dosw. Microbiol., 60(1): 59-63.

14. Helms, M., Simonsen, J., Olsen, K.E. and Molbak, K. (2005) Adverse health events associates with antimicrobial drug resistance in Campylobacter spp.: A registry based cohort study. J. Infect. Dis., 191(7): 1050-1055.

15. Marshall, B.M. and Levy, S.B. (2011) Food Animals and Antimicrobials: Impacts on Human Health. Clin. Microbiol. Rev., 24(4): 718-733.

16. Wilson, D.L., Rathinam, V.A., Qi, W., Wick, L.M., Landgraf, J., Bell, J.A., Plovanich-Jones, A., Parrish, J., Finley, R.L., Mansfield, L.S. and Linz, J.E. (2010) Genetic diversity in 
Campylobacter jejuni is associated with differential colonization of broiler chickens and C57BL/6J IL10-deficient mice. Microbiology, 156(7): 2046-2057.

17. Young, K.T.; Davis, L.M. and DiRita, V.J. (2007) Campylobacter jejuni: Molecular biology and pathogenesis. Nat. Rev. Microbial., 5: 665-679.

18. Alary, M. and Nadeau, D. (1990) An outbreak of Campylobacter enteritis associated with a community water supply. Can. J. Public Health, 81: 268-271.

19. Anderson, Y., Dejong, B. and Studahl, A. (1997) Waterborne Campylobacter in Sweden - the cost of an outbreak. Water Sci. Technol., 35: 11-14.

20. Itoh, T., Saito, K., Maruyama, T., Sakai, S.,Ohashi, M. and Oka, A. (1980) An outbreak of acute enteritis due to Campylobacter fetus subspecies jejuni at a nursery school of Tokyo. Microbiol. Immunol., 24: 371-379.

21. Fitzgerald, C. and Nachamkin, I. (2007) Campylobacter and Arcobacter. In: Manual of Clinical Microbiology. ASM Press, Washington, DC. p933-946.

22. Millson, M., Bokhout, M., Carlson, J., Spielberg, L., Aldis, R., Borczyk, A. and Lior, H. (1991) An outbreak of Campylobacter jejuni gastroenteritis linked to melt water contamination of a municipal well. Can. J. Public Health, 82: 27-31.

23. Rautelin, H. and Hanninen, M.L. (2000) Campylobacters: The most common bacterial enteropathogens in the Nordic countries. Ann. Med., 32: 440-445.

24. CDC. (2011) CDC Estimates of Foodborne Illness in the United States. Available from: http://www.cdc.gov/foodborneburden/2011-foodborne-estimates.html. Accessed on 30.09.2013.

25. Taylor, D.E. and Chang, N. (1991) In vitro susceptibilities of Campylobacter jejuni and Campylobacter coli to azithromycin and erythromycin. Antimicrob. Agents Chemother., 35: 1917-1918.

26. Ikram, R., Chambers, S., Mitchell, P.,Brieseman, M.A. and Ikam, O.H. (1994) A case control study to determine risk factor for Campylobacter infection in christchurch in the summer of 1992-93. N. Z. Med. J., 107: 430-432.

27. Salihu, M.D., Junaidu, A.U., Magaji, A.A. and Rabiu, Z.M. (2010) Study of Campylobacter in raw cow milk in Sokoto State, Nigeria. Br. J. Dairy Sci., 1(1): 1-5.

28. Lastovica, A.J. and Allos, M.B. (2008) Clinical significance of Campylobacter and related species other than Campylobacter jejuni and Campylobacter coli. In: Nachamkin, I., Szymanski, C.M. and Blaser, M.J., editors. Campylobacter, $3^{\text {rd }}$ Edn, American Society for Microbiology, Washington, D.C., pp. 123-150.

29. Clinical and Laboratory Standards Institute. (2005) Methods for Antimicrobial Dilution and Disk Susceptibility Testing of Infrequently Isolated or Fastidious Bacteria; Proposed Guideline. CLSI document M45-P. Clinical and Laboratory Standards Institute, Wayne, Pennsylvania, USA.

30. External Quality Assurance System (EQAS). (2013) Protocol National Food Institute, Technical University of Denmark (DTU Food), in Collaboration with Partners and Regional Sites in WHO GFN. Available from: http:// www.antimicrobialresistance.dk/data/images/eqas/ who_2013-protocol-text.pdf. Accessed on 30.12.2013.

31. Crushell, E., Harty, S., Sharif, F. and Bourke, B. (2004) Enteric campylobacter: Purging its secrets? Pediatr. Res., 55(1): 3-12.

32. Ziprin, R. L., Young, C. R., Byrd, J.A., Stanker, L.H., Hume, M.E., Gray, S.A., Kim, B. J. and Kim, M.E. (2001) Role of Campylobacter jejuni potential virulence genes in cecal colonization. Avian Dis., 45: 549-557.

33. Ziprin, R. L., Young, C.R., Stanker, L.H., Hume, M.E. and Konkel, M.E. (1999) The absence of cecal colonization of chicks by a mutant of Campylobacter jejuni not expressing bacterial fibronectin-binding protein. Avian Dis., 43: 586-589.

34. Carvalho, A.C., Ruiz-Palacios, G.M., Ramos-Cervantes,
P., Cervantes, L. E., Jian, X. and Pickering, L.K. (2001) Molecular characterization of invasive and non-invasive Campylobacter jejuni and Campylobacter coli isolates. $J$. Clin. Microbiol., 39: 1353-1359.

35. Poly, F. and Guerry, P. (2008) Pathogenesis of Campylobacter. Curr. Opin. Gastroenterol., 24(1): 27-31.

36. Kazemeini, H., Valizade, Y., Parsaei, P., Nozarpour, N. and Rahimi, E. (2011) Prevalence of Campylobacter Species in Raw Bovine Milk in Isfahan, Iran. Middle East J. Sci. Res., 10(5): 664-666.

37. Wysok, B., Wiszniewska, A.,Uradziński, J. and Szteyn, J. (2011) Prevalence and antimicrobial resistance of Campylobacter in raw milk in the selected areas of Poland. Pol. J. Vet. Sci., 14(3): 473-477.

38. Rahimi, E., Sepehri, S. and Momtaz, H. (2013) Prevalence of Campylobacter species in milk and dairy products in Iran. Rev. Méd. Vét., 164(5): 283-288.

39. Lovett, J., Francis, D.W. and Hunt, J.M. (1983) Isolation of Campylobacter jejuni from raw milk. Appl. Environm. Microbiol., 46(2): 459-462.

40. Elango, A., Dhamlakshmi, B., Pugazhenthi, T.R., Jayalalitha, V., Kumar, C.N. and Doraisamy, K.A. (2009) PCR- Restriction fragment length polymorphism of Campylobacter jejuni isolates. Egypt. J. Dairy Sci., 37: 169-173.

41. Italian Republic. (2007) Permanent Council State-Regions and Autonomous Provinces. AccordoStato - Regioni e Province Autonome 25-1-2007. Official Gazette No. 36 of $13^{\text {rd }}$ of February, 2007. Rome.

42. Singh, H., Rathore, R.S., Singh, S. and Cheema, P.S. (2009) Comparative analysis of cultural isolation and PCR based assay for detection of Campylobacter jejuniin food and faecal samples. Braz. J. Microbiol., 42(1): 181-186.

43. Wicker, C., Giordano, M., Rouger, S.,Sorin, M. L. and Arbault, P. (2001) Campylobacter detection in food using an ELISA based method. Int J. Med. Microbiol., 291(31): $1-12$.

44. Jayarao, B.M., Donaldson, S.C., Straley, B.A., Sawant, A.A., Hegde, N.V. and Brown, J.L. (2006) A survey of foodborne pathogens in bulk tank milk and raw milk consumption among farm families in Pennsylvania. J. Dairy Sci., 89(7): 2451-2458

45. Martin, T., Hulsey, J., Basye, D., Blush, G. Anderson, S. and Neises, D. (2007) Campylobacteriosis outbreak associated with unpasteurized milk- Reno county and Butler county. Kenvas Department of Health and Environment.

46. Khanzadi, S., Jamshidi, A., Soltaninejad, V. and Khajenasiri, S. (2010) Isolation and identification of Campylobacter jejuni from bulk tank milk in Mashhad- Iran. World Appl. Sci. J., 9(6): 638-643.

47. Giacometti, F., Serraino, A., Finazzi, G., Daminelli, P., Losio, M.N., Arrigoni, N., Piva, S., Florio, D.,Riu, R. and Zanoni, R.G. (2012) Sale of raw milk in Northern Italy: Safety implications and comparison of different analytical methodologies for detection of foodborne pathogens. Foodborne Pathog. Dis., 9: 293-297.

48. Mabotel, K.I., Mbewel, M., Ateba, C.N. and Beighle, D. (2011) Prevalence of Campylobacter contamination in fresh chicken, meat and milk obtained from markets in the NorthWest province, South Africa. J. Hum. Ecol., 36(1): 23-28.

49. Serraino, A., Florio, D., Giocometti, F., Piva, S., Mion, D. and Zanoni, R.G. (2013) Presence of Campylobacter and Arcobacter species in in-line milk filters of farms authorized to produce and sell raw milk and of a water buffalo dairy farm in Italy. J. Dairy Sci., 96(5): 2801-2807.

50. Giacometti, F., Bonilauri, P., Serraino, A., Peli, A., Amatiste, S., Arrigoni, N., Bianch, M., Bilei, S., Cascone, G., Comin, D., Daminelli, P., Decastelli, L., Fustini, M., Mion, R., Petruzzelli, A., Rosmini, R., Rugna, G., Tamba, M., Tonucci, F. and Bolzoni, G. (2013) Four-Year monitoring of foodborne pathogens in raw milk sold by vending machines in Italy. J. Food Prot., 11: 1824-1993. 
51. Jain, N. and Shrivastava, S. (2012) Study on bacteriological quality of marketed milk product (Indian Cheese) in Bhopal City, Madhya Pradesh, India. Sci. Secur. J. 2: 47-51.

52. Vaishnavi, C., Singh, S., Grover, R. and Singh, K. (2001) Bacteriological study of Indian cheese (paneer) sold in Chandigarh. Indian J. Med. Microbiol., 19(4): 224-226.

53. Chatur, Y.A., Brahmbhatt, M.N., Modi S. and Nayak J.B. (2014) Fluoroquinolone resistance and detection of topoisomerase gene mutation in Campylobacter jejuni. Int. J. Curr. Microbiol. Appl. Sci., 3(6): 773-783.

54. Murphy, G.J., Echeveria, P., Jackson, L., Arness, M., Lebron, C. and Pitangrasi, C. (1996) Ciprofloxacin - and azithromyan-resistant Campylobacter causing traveler's diarrhea in US troops deployed to Thailand on 1994. Clin. Infect. Dis., 22(5): 868-869.

55. Bopp, C.A., Birkness, K.A.,Wachsmuth, I.K. and Barrett, T.J. (1985) In vitro antimicrobial susceptibility, plasmid analysis, and serotyping of epidemic-associated Campylobacter jejuni. J. Clin. Microbiol., 21: 4-7.

56. Wegmuller, B., Lüthy, J. and Candrian, U. (1993) Direct polymerase chain reaction detection of Campylobacter jejuni and Campylobacter coli in raw milk and dairy products. Appl. Environ. Microbiol., 59(7): 2961-2965.

57. Fischer, S.H. and Nachamkin, I. (1991) Common and variable domains of the flagellin gene, flaA, in Campylobacter jejuni. Mol. Microbiol., 5(5): 1151-1158.

58. Nuijten, P.J., Asten, F.J.V., Gaastra, W. and Van der Zeijst, B.A. (1990) Structural and functional analysis of two Campylobacter jejuni flagellin genes. J. Biol. Chem., 265(29): 17798-17804.

59. Guerry, P., Logan, S.M., Thornton, S. and Trust, T.J. (1990) Genomic organization and expression of Campylobacter flagellin genes. J. Bacteriol., 172(4): 1853-1860.

60. Wassenaar, T.M., Bleumink-Pluym, N.M.C., Newell, D.G., Nuijten, P.J.M. and Van Der Zeijst B.A.M. (1994) Differential flagellin expression in a flaAflaB + Mutant of Campylobacter jejuni. Infect. Immun., 62(9): 3901-3906.

61. Wassenaar, T.M., Van Der Zeijst, B.A.M., Ayling, R. and Newell, D.G. (1993) Colonization of chicks by motility mutants of Campylobacter jejuni demonstrates the importance of flagellinA expression. J. Gen. Microbiol., 139: 1171-1175.

62. Wassenaar, T.M. (2000) Molecular methods for detection, speciation and subtyping of Campylobacter spp. Lohmann inf., 24: 13-19.

63. Al-Amri, A., Senok, A.C., Ismaeel, A.Y., Al-Mahmeed, A.E. and Botta, G.A. (2007) Multiplex PCR for direct identification of Campylobacter spp. in human and chicken stools. $J$. Med. Microbiol., 56(10): 1350-1355.

64. Cloak, O.M. and Fratamico, P.M. (2002) A multiplex polymerase chain reaction for the differentiation of Campylobacter jejuni and Campylobacter coli from a swine processing facility and characterization of isolates by pulsed-field gel electrophoresis and antibiotic resistance profiles. J. Food Protect., 65(2): 266-273.

65. Nayak, R., Stewart, T.M. and Nawaz, M.S. (2005) PCR identification of Campylobacter coli and Campylobacter jejuni by partial sequencing of virulence genes. Mol. Cell Probes, 19(3): 187-193.

66. Konkel, M.E., Gray, S.A., Kim, B.J.,Garvis, S.G. and Yoon, J. (1999a) Identification of the enteropathogens
Campylobacter jejuni and Campylobacter coli based on the $c a d \mathrm{~F}$ virulence gene and its product. J. Clin. Microbiol., 37(3): 510-517.

67. Al-Mahmeed, A., Senok, A.C., Ismaeel, A.V., Bindayna, K.M., Tabbara, K.S. and Botta, G.A. (2006) Clinical relevance of virulence genes in Campylobacter jejuni isolates in Bahrain. J. Med. Microbiol., 55(7): 839-843.

68. Rizal, A., Kumar, A. and Vidyarthi, A.S. (2010) Prevalence of pathogenic genes in Campylobacter jejuni isolated from poultry and human. Internet J. Food Saf., 12: 29-34.

69. Sanad, Y.M., Kassem, I.I., Liu, Z., Lin, J., LeJeune, J.T., Jeffrey, T. and Rajashekara, G. (2011) Occurrence of the invasion associated marker (iam) in Campylobacter jejuni isolated from cattle. BMC Res. Notes, 4: 570.

70. Wieczorek, K. and Osek, J. (2010) Molecular characterization of Campylobacter spp. isolated from poultry faeces and carcasses in Poland. Acta Vet. Brno., 80: 019-027.

71. Hendrixson, D.R. (2006) A phase-variable mechanism controlling the Campylobacter jejuni FlgR response regulator influences commensalism. Mol. Microbiol., 61(6): 1646-1659.

72. Hendrixson, D.R. (2008) Restoration of flagellar biosynthesis by varied mutational events in Campylobacter jejuni. Mol. Microbiol., 70(2): 519-536.

73. Karenlampi, R., Rautelin, H. and Hanninen, M.L. (2007) Evaluation of genetic markers and molecular typing methods for prediction of sources of Campylobacter jejuni and C. coli infections. Appl. Environ. Microbiol., 73(5): 1683-1685.

74. Bang, D.D., Nielsen, E.M., Scheutz, F., Pedersen, K., Handberg, K. and Madsen, M. (2003) PCR detection of seven virulence and toxin genes of Campylobacter jejuni and Campylobacter coli isolates from Danish pigs and cattle and cytolethal distending toxin production of the isolates. J. Appl. Microbiol., 94(6): 1003-1014.

75. Konkel, M.E., Kim, B.J., Rivera, A.V. and Garvis, S.G. (1999) Bacterial secreted proteins are required for the internalization of Campylobacter jejuni into cultured mammalian cells. Mol Microbiol., 32(4): 691-701.

76. Acik, M.N., Karahan, M., Ongor, H., Karagulle, B. and Cetinkaya, B. (2013) Investigation of cytolethal distending toxin production and virulence genes in Campylobacter isolates from cattle. Rev. Méd. Vét., 164(5): 272-277.

77. Khoshbakht, R., Tabatabaei, M. Shirzad, A.H. and Hosseinzadeh, S. (2014) Occurrence of virulence genes and strain diversity of thermophilic campylobacters isolated from cattle and sheep faecal samples. Iran. J. Vet. Res., Shiraz Univ. 15(2): 138-144.

78. Linton, D., Owen, R.J. and Stanley, J. (1996) Rapid identification by PCR of the genus Campylobacter and of five Campylobacter species enteropathogenic for man and animals. Res. Microbiol., 147(9): 707-718.

79. Linton, D., Lawson, A.J., Owen, R.J. and Stanley, J. (1997) PCR detection, identification to species level, and fingerprinting of Campylobacter jejuni and Campylobacter coli direct from diarrheic samples. J. Clin. Microbiol., 35(10): 2568-2572.

80. Nachamkin, I., Bohachick, K. and Patton, C.M. (1993) Flagellin gene typing of Campylobacter jejuni by restriction fragment length polymorphism analysis. J. Clin. Microbiol., 31(6): 1506-1531. 